\title{
Women's entrepreneurship, Neoliberalism and Economic Justice in the Postfeminist Era: A Discourse Analysis of Policy Change in Sweden
}

\author{
Berglund, Karin, Stockholm University \\ Ahl, Helene, Jönköping University \\ Pettersson, Katarina, Swedish University of Agriculture \\ Tillmar, Malin, Linköping and Linnaeus University
}

\begin{abstract}
Since the early 1990s there has been investment in women's entrepreneurship policy (WEP) in Sweden, which continued until 2015. During the same period, Sweden assumed neoliberal policies that profoundly changed the position of women within the world of work and business. The goals for women's entrepreneurship policy changed as a result, from entrepreneurship as a way to create a more equal society, to the goal of unleashing women's entrepreneurial potential so they can contribute to economic growth. To better understand this shift we approach WEP as a neoliberal governmentality which offers women “entrepreneurial” or "postfeminist” subject positions. The analysis is inspired by political theorist Nancy Fraser who theorized the change as the displacement of socioeconomic redistribution in favour of cultural recognition, or identity politics. We use Fraser's concepts in a discourse analysis of Swedish WEP over two decades, identifying two distinct discourses and three discursive displacements. Whilst WEP initially gave precedence to a radical feminist discourse that called for women's collective action, this was replaced by a postfeminist neoliberal discourse that encouraged individual women to assume an entrepreneurial persona, start their own business, compete in the marketplace and contribute to economic growth. The result was the continued subordination of women business owners, but it also obscured, or rendered structural problems/solutions, and collective feminist action, irrelevant.
\end{abstract}

Key words: Women's entrepreneurship policy, discourses of recognition and redistribution, discursive displacements, neoliberalism, postfeminism. 


\section{Introduction}

Since the 1980s, neoliberal policies have transformed western liberal democratic welfare states, with profound changes for the position of women within the world of work and business (Baccaro \& Howell, 2011; Braedley \& Luxton, 2010; Kingfisher, 2013; Lombardo, Meier \& Verloo, 2009). Changes include privatization of former public services, marketization of formerly unpaid work in the household, the demise of unions, an emergence of temporary and precarious work, cost-benefit calculations extending to all spheres of life, and the privileging of entrepreneurship as the route to economic growth and prosperity (Brown, 2003; Harvey, 2005; Larner, 2000; Perren \& Dannreuther, 2013).

As a result, women are encouraged to start their own businesses through public policy measures, but the outcomes may not always be to women's advantage. The development in Sweden, our case country, is a clear example. Whilst the number of women-owned businesses increased, the gendered pattern of work remained the same - women started businesses in low-paid service and personal care sectors (Sköld \& Tillmar, 2015). Privatizations of businesses with economies of scale, such as hospitals, resulted in male-owned oligopolies who turned to cheaper, less qualified labour and offered women jobs with precarious working conditions (Sköld, 2015; Sundin \& Tillmar, 2010; Thörnquist, 2014).

Feminist policy analyses have found entrepreneurship policy to assume that women must be 'fixed' in relation to a masculine norm (Ahl \& Marlow, 2012), to subordinate women's wellbeing to goals of economic growth (Ahl, Berglund, Pettersson, \& Tillmar, 2016), and to suppress or coopt goals of social justice and gender equality (Ahl \& Nelson, 2015; Lombardo et al., 2009).

Neoliberal policies have also meant an individualization of society (Lemke, 2001) and fostered a new subjectivity, the "entrepreneurial self” (Bröckling, 2015), where the individual must constantly work on herself to compete successfully in the extended marketplace (Scharff, 2016). The neoliberal ideology has also given feminism a new shape. The idea of feminist, collective action for the improvement of the position of women has been replaced, or coopted by the ideology of postfeminism, in which every (wo)man is the smith of her own fortune (Gill, 2007). Postfeminism assumes that necessary feminist victories in terms of equal access to resources have been won, and now is the time for individual women to avail themselves of opportunities on a meritocratic basis (Gill, 2007; McRobbie, 2004).

In Oksala's (2013) analysis, neoliberalism should be understood as governmentality in a Foucauldian sense - a set of ideas and assumptions that affect not only the economy, but also how we construct the self and the social, how we choose to conduct ourselves, what options we see and what actions are perceived as feasible. In neoliberal governmentality, postfeminist ideals become naturalized and taken for granted - they render alternative options, such as feminist collective action, obsolete (McRobbie, 2009).

Policy to encourage individual women to become successful through entrepreneurship is thus logical and expected, but the results are perhaps not. We see no reason to believe that those 
who formulate policies for women's entrepreneurship - in Sweden, largely women's advocates - had anything but women's best interests in mind. The situation is puzzling.

We probe these issues through a longitudinal analysis of policy. Using official Swedish policy documents as our empirical material we conduct a Foucauldian discourse analysis from the inception of women's entrepreneurship policy in 1993 until its conclusion in 2015. During this period, Sweden underwent a shift of political rule, from a redistributive welfare state towards a society in which neoliberal politics and feminism merged (Wottle \& Blomberg, 2011), which makes the analysis timely.

To assist the analysis, we employ political theorist Nancy Fraser's concept of displacement, and turn it into a methodological approach. Fraser (1995, 1997b, 2000) holds that because of neoliberalism, the struggle for cultural recognition, also referred to as identity politics, has displaced socioeconomic redistribution. Using Fraser's framework, our analysis traces the discursive use and occurrence of recognition and redistribution in women's entrepreneurship policy over time, asking if and in which ways policy has taken part in the displacement from socioeconomic redistribution to cultural identity recognition. The purpose of the article is thus twofold: First, to develop and apply a discourse analytical method based on Fraser's concepts, and second, to use the method to analyse changes over time in women's entrepreneurship policy.

Previous studies of women's entrepreneurship policy have addressed the content of policy, compared countries, or looked at outcomes (see Link \& Strong, 2016 for an overview). They are chiefly cross-sectional and focus on the aspect of economics. We therefore add to existing research in three ways: by approaching neoliberalism as a form of governmentality, by studying how it has influenced policy formulation over time, and by developing a methodological approach for such analysis.

The article is organized as follows: After a literature review, we introduce the theoretical framework, and then the material and method. The results are thereafter presented in two steps: First, we identify two discourses - on gender equality in the early period, and on economic growth in the latter. Second, we identify three discursive displacements that made the shift from the first to the second discourse possible. We conclude by discussing the consequences of this shift for women and for the feminist project.

\section{Theoretical framework}

\section{Postfeminism and its reflection in entrepreneurship policy}

This study builds on recent feminist theorizing on postfeminism as a ubiquitous and persuasive cultural formation which purports to offer women a better life through their engagement with consumption (Tasker \& Negra, 2007), regulation of femininity (McRobbie, 2004, 2009), and entrepreneurial endeavours (Lewis, 2014). We see postfeminism as an effect of the neoliberal society, in which feminism is rephrased as individual success rather than collective struggle. Propelled by advancing neoliberalism, postfeminism reframes what is 
regarded as "normal and desirable in regard to gender, femininity and feminism" in contemporary society (Sullivan \& Delaney, 2017, p. 838). Notions of entrepreneurship, entrepreneurialism or the entrepreneurial self (Bröckling, 2005; du Gay, 2004; Lemke, 2001) are situated at the heart of postfeminism. The entrepreneurial subject of neoliberalism and the “active, freely choosing, self-reinventing subject of postfeminism” (Gill \& Scharff, 2013 p. 7) breed each other, with consequences for how feminist progress is understood: as an individual rather than collective project (Ahl \& Marlow, 2017; Lewis, 2014; Lewis, Benschop \& Simpson, 2017).

The notion of postfeminism first emerged in cultural and media studies and was used to describe contemporary representations of women and femininity in media and culture, namely as youthful, sexually liberated, independent working women who have achieved success of their own accord in a world where gender discrimination is a non-issue (Gill, 2007, McRobbie, 2004, 2009, 2011). Postfeminism sees femininity as a bodily property and individualism, choice and empowerment as the primary routes to women's independence and freedom (Bröckling, 2005; Gill, 2007, Lewis \& Simpson, 2016).

Postfeminist tropes are thus typically empowering, offering women avenues for reaching their full potential, freedom and independence (Scharff, 2016). But to reach this 'freedom' female subjects must submit to self-surveillance, self-discipline and self-commodification technologies (Gill \& Scharff, 2013; Lewis et al., 2017). Achiveing the image of the successful postfeminist woman thus requires a constant critical gaze on the self - it is an achievement that takes effort (Tasker \& Negra, 2007, Butler 2013). Postfeminism assumes that gender equality has been achieved and feminist activism is no longer necessary. Thus, postfeminism is not feminism, but neither does it oppose feminism; rather, it co-opts it (McRobbie, 2004). By equating feminist progress with individual success, it silences versions of feminism "characterized by a critical orientation and a collectivist spirit based on mutual struggle, communal relations with other women and the search for collective solutions to shared problems” (Lewis, Benschop, \& Simpson, 2017:217).

Contemporary policy for women's entrepreneurship expresses and reflects the neoliberal and postfeminist ethos. Policy for women's entrepreneurship is a global, and growing phenomenon, largely motivated by women's actual or potential contributions to economic growth (APEC, 2011; Henry, Orser, Coleman \& Foss, 2017; OECD, 2014). Research on women's entrepreneurship is also a growing field (Ahl, 2006; Jennings \& Brush, 2013), but is, at large, only marginally concerned with policy - a recent systematic literature review of articles in leading entrepreneurship research journals found that policy implications, if discussed at all, were found to be "vague, conservative, and centre on identifying skills gaps in women entrepreneurs that need to be 'fixed', thus isolating and individualizing any perceived problem” (Foss, Henry, \& Ahl, 2014). Similarly, an annotated bibliography of the gender and entrepreneurship literature found that less than $4 \%$ of 563 studies addressed the impact of public policy (Link \& Strong, 2016). With few exceptions, these studies concerned the identification of women's specific assistance needs and how to design training and business support to cater to them; or, alternatively, evaluated how well support systems 
managed to do this (e.g. Bertaux \& Crable, 2007; Botha, Nieman \& van Vuuren, 2006). The focus on "fixing" individual women and the concomitant disregard of structural constraints is entirely aligned with a neoliberal and postfeminist agenda.

However, a small stream of literature has studied the relationship between women's entrepreneurship and different welfare state policies. The authors typically rely on EspingAndersen's (1990, 2009) characterization of welfares state regimes as either conservative, liberal or social democratic/Nordic. In conservative welfare states with a strong male breadwinner norm, and in liberal welfare states that rely on the market for welfare services, lack of affordable child care makes full-time employment difficult, so many women start a livelihood business to both secure an income and care for a family (Tonoyan, Budig \& Strohmeyer, 2010). But self-employment does not offer all women the same opportunities. Large comparative cross-national studies of the development in Western states show a bifurcation between women in professional and non-professional self-employment (GurleyCalvez, Harper, \& Biehl, 2009; Tonoyan, Budig, \& Strohmeyer, 2010). Neoliberal policies such as short-term outsourcing instead of employment, along with an expansion of the service sector, have caused an increase in the number of self-employed freelancing professionals, as well as an increase in the number of individuals, particularly women, engaged in low-skilled and unstable self-employment (Arum \& Müller, 2004). These groups have very different conditions. Data from the USA showed that while professional self-employed women received the same earnings premium as their male counterparts, wives and mothers, in particular, in non-professional occupations suffered an earnings penalty (Budig, 2006a, 2006b). The high concentration of non-professional self-employed women in child care accounted for much of these penalties (Budig, 2006a, 2006b). Further, the women in this category make the careers of the professional women possible in the first place. Wolf (2013) describes this as the return of the servant classes eroding the base for solidarity among women. The careers of well-educated, middle-class women in neoliberal/postfeminist society are thus conditional on the care work of other, less well-paid women. Whilst some welleducated, middle-class women can 'lean in' and make a career, they may also need to 'lean on’ other women to step in and do the care work (Gutting \& Fraser, 2015).

In a global comparison, the Nordic states offer women unique opportunities to combine parenthood and work, with generous parental leave policies, publicly organized and subsidised day care, or the statutory right for either parent to stay home with a sick child, also paid (Sainsbury, 1999). Part and parcel of this system is a large public sector, with public schools and universities, public health care, and public child care, that provides employment opportunities for many women. Since income replacement in these systems, such as for parental leave, is tied to income from paid employment, employment rather than entrepreneurship becomes the norm (Klyver, Nielsen, \& Evald, 2013). In Sweden, women’s participation rate in the labour market almost equals men's $-84 \%$ and $89 \%$ respectively (Statistics Sweden, 2016). In fact, countries that actively promote gender equality through a progressive family and labour market policy may discourage women's entrepreneurship (Klyver, Nielsen, \& Evald, 2013; Neergaard \& Thrane, 2011). 
Nonetheless, Sweden too has seen an increase in women's entrepreneurship. Historically, women owned around 25\% of all businesses in Sweden, but in 2015 this figure was 30\% (Statistics Sweden, 2017). The proportion of women employed by the public sector meanwhile decreased from 58\% in 1987 to 47\% in 2015 (Statistics Sweden, 2016). The development coincides with neoliberal policy changes in Sweden, including a reduced public sector through marketization of public services, and suggests that government programmes intended to encourage women to start businesses in former public operations have been successful. But this does not necessarily mean success for the individual woman, and it has not changed the gendered pattern of work (Sundin \& Tillmar, 2010). As elsewhere, most women entrepreneurs in Sweden are still found in social work, and in personal and cultural services, that are often small livelihood businesses with low earnings potential (SCB, 2017). Instead of challenging this pattern, neoliberal reforms have rather exacerbated it. A Swedish 25-year longitudinal study tracing the results of marketization of public sector operations that were women-dominated by employment, concluded that almost all the increase in women's business ownership was found in child care (Sköld, 2015; Sköld \& Tillmar, 2015). Ownership of more lucrative businesses such as hospitals, schools or homes for the elderly went to men Sundin \& Tillmar (2010) speak of the oligopolization and masculinization of the former public sector. Moreover, this has changed the conditions for women working in these sectors. Thörnquist (2014) found a tendency to underbid for public sector contracts, resulting in the use of cheap, often less qualified labour and in more difficult working conditions than in public sector jobs. Other reforms, such as the introduction of a 50\% tax break for the purchase of household services such as cleaning, resulted, as predicted, in more women-owned companies in the cleaning sector, but also a downgrading of jobs, precarious employment, increased job polarization and increased income inequalities (Gavanas, 2013; Sköld \& Heggeman, 2012; Åberg, 2013). So, while Swedish policy has argued that neoliberal reforms along with an increase in women-owned businesses will benefit both the economy and women (Proposition, 1993/94:140, 2001/02:4, 2006/07:94), the outcomes indicate that this is not so. Feminist studies demonstrate that the neo-liberal growth paradigm, which underpins entrepreneurship policy in Sweden have had this effect (Pettersson, 2012, Pettersson, Ahl, Berglund \& Tillmar, 2017, Rönnblom 2009). Swedish entrepreneurship policy was found to subordinate women's well-being to goals of economic growth, or assumed that increased gender equality automatically would result from growth (Ahl et al., 2016); support systems were tailored in such a way that men's businesses were favoured (Berglund \& Granat Thorslund, 2012; Hedlund, 2011; Nutek, 2007) and policy and programmes positioned women as an 'other' in need of being 'fixed' in relation to a masculine norm (Ahl \& Nelson, 2015; Nilsson, 1997).

But while neoliberalism is often defined as a way of organizing the economy, with cut-backs in public spending and a dismantling and privatization of the public sector, underpinning the emergence of temporary and precarious work, in particular for women (Brown, 2003; Harvey, 2005; Larner, 2000), it does not only affect the economy; it has discursive effects reaching far beyond the economy. Neoliberalism extends market rationality (e.g. cost-benefit calculation, efficiency, competition) to all institutions, social practices and subjectivities, effectively eradicating the boundaries between the social and the economic (Bröckling, 2005; Dean, 
1999; Rose, 1993). Seen this way, neoliberalism is not just a model for the organization of the economy, but a specific kind of governmentality, a "conduct of conduct” (Foucault, 2003), with consequences for all facets of life, the most important perhaps concerns how the room for political deliberation has changed, or rather shrunk (Oksala, 2013). This tends to limit the space for political interventions, as democratic decisions are replaced by taken-for-granted economic truths. As Gill (2008 p. 443) argues: “...this neoliberal postfeminist moment is importantly - perhaps pre-eminently - one in which power operates psychologically, by "governing the soul" ... Indeed, it is not simply that subjects are governed, disciplined or regulated in ever more intimate ways, but even more fundamentally that notions of choice, agency and autonomy have become central to that regulatory power." Swedish policy studies demonstrate that the idea that the position of women can be improved through individual women's business ownership has indeed rendered women's collective, political action irrelevant (Ahl et al., 2016; Pettersson et al., 2017). Neoliberal policy has limited the space for conventional feminist action; women's collective action through the state, or through women's policy agencies (Outshoorn \& Kantola, 2007). We posit that policy itself formulation as well a program design - has contributed to this change: it has made certain subject positions and actions desirable and other unthinkable. But to analyse this systematically, we need analytical tools that enable a detailed study over time, to which we now turn.

\section{Nancy Fraser on recognition, redistribution and discursive displacements}

In our theorizing of postfeminism we turn to feminist philosopher and political theorist Nancy Fraser (1995, 1997b, 2000). Her analysis of the changing conditions for feminism in her seminal work Justice Interruptus (Fraser, 1997b) provides us with a lens for understanding the emergence and the consequences of 'the postfeminist condition'. Fraser's object of theorizing is social justice. Reaching justice, according to Fraser, takes both recognition (a remedy for cultural injustices) and redistribution (a remedy for socioeconomic injustices). Fraser views socioeconomic injustice as rooted in political-economic structures of society and expressed as economic marginalization, exploitation and deprivation (Fraser 1995, p. 70-71). Cultural injustice is grounded in social patterns of representation, interpretation and communication and exemplified as cultural domination, non-recognition and disrespect (Fraser 1995, p. 70-71). These two kinds of injustice require different remedies. Recognition is pivotal to fight cultural domination and redistribution is crucial to fight economic marginalization. Fraser makes the distinction between recognition and redistribution for analytical purposes, and to help formulate a radical politics that takes both remedies into account (Fraser, 2000). In actual experience, recognition and redistribution are entangled and both are necessary requirements for justice, but the relationship between them is dilemmatic. When recognition calls attention to the specificity of one group, it seeks to promote group differentiation, and when redistribution calls for equal treatment (e.g. the same salary for men and women) it promotes group de-differentiation (Fraser, 1995, p.74). Recognition can be seen as a major advancement in relation to a reductive economic discourse which does not adequately allow for a theoretical conception of the injustice and harm that had its roots in androcentric cultural patterns. On the other hand, recognition detached from redistribution tends to reify femininity and gloss over other mechanisms of subordination (Fraser, 1997b). 
Fraser shares the concern on how the collective, and power dimension of the feminist project, is lost in the neoliberal translation of feminism. Fraser views politics as integral to this translation and is concerned with how feminist ideas, involving anticapitalistic ethos, critique of 'profit over people' and ambitions to upset structures of production and reproduction, have been "twisted to serve neoliberal, capitalist ends" (Gutting \& Fraser, 2015, p, 4). In the late twentieth century, the struggle for cultural recognition, also referred to as identity politics, became a political model which has heeded feminist claims of changing social patterns of representation, recognizing 'othered' cultures and respecting individuals irrespective of their sex, age, religion, ethnicity, etc. (Fraser, 2000, 2013). Fraser does not oppose this but argues that a politics of recognition must be combined with a redistributive politics to not further spur neoliberal governmentality and pull the rug from underneath its feet of a collective feminism. Because if "individual freedom" gives precedence to the freedom of some individual women before others, this undermines feminist goals of changing structures that discriminate women at large.

Fraser (2000) maintains, however, that the politics of recognition has displaced socioeconomic redistribution; a politics with ambitions to find remedies for economic marginalization, exploitation and deprivation rooted in political-economic structures of society. Following Fraser's thoughts, it is not only a politics of recognition that has displaced a politics of redistribution, but in parallel, the conception of success as individual achievement in postfeminism has displaced a collective feminism. Fraser's main concern is how neoliberalism has weakened feminism as a collective movement by dividing feminist interests and social groups and setting them against each other (Fraser, 1997b). The displacement of redistributive politics by a politics of recognition has contributed to this. Because, recognition does not adequately "complicate and enrich redistributive struggles”, but, rather, can be said to "marginalize, eclipse and displace them” (Fraser, 2000, p. 108). She terms this a problem of displacement, implying that the politics of recognition displaces a politics of redistribution (Fraser, 2000, p. 108).

Although Fraser's ideas have been subject to debate regarding their privileging of economic justice (Alcoff, 2007; Butler, 1997; Fraser,1997a; Nilsson, 2008; Oksala, 2013; Swanson, 2005), they are appropriate and applicable to our argument because of the transition in policy focus over time from economic redistribution to individual economic production. However, while Fraser's theory is heuristic, we use it as a tool for empirical inquiry. We do not a-priori assume that recognition has displaced redistribution in policy for women's entrepreneurship but use this conceptual pair to ask questions to our empirical material so that we can trace if, and what kind of, displacements have occurred over time. This approach allows us to see possible nuances and paradoxes in the material. There have, to our knowledge, been few attempts to apply Fraser's concepts of recognition and redistribution as analytical tools for empirical inquiry (for an exception see Skalli, 2011), and none to develop a methodological approach.

In summary, our theoretical framework says that neoliberal changes, reflected in policy for 
women's entrepreneurship, have produced new discourses on entrepreneurship, gender and feminism, and offered women new subject positions while foreclosing others. In a Foucauldian understanding, this has power effects (Foucault, 1972a). The productive power, at work here, manifests itself by producing knowledge, or discourses, that are freely taken up by individuals, as they are seen as good for them. It works as a governmentality; it makes individuals govern themselves in certain directions (Foucault, 2003). In neoliberal governmentality this direction typically includes a transfer of responsibility from the collective to the individual (Berglund et al. 2017). The postfeminist discourse thus has particular power implications for women and for the feminist project. Not only does it risk prolonging women's subordination to men, it invites individual women to freely participate in the endeavor. Moreover, the postfeminist discourse results in a demise of the feminist project as a collective and political undertaking. Nancy Fraser's theory on how recognition of identities has displaced redistribution of resources offers a way to understand or further illuminate how the postfeminist condition came about. We use Fraser's theory to develop an analytical tool for empirical inquiry. Our analysis traces the discursive use and occurrence of recognition and redistribution in women's entrepreneurship policy over time, asking if and in which ways policy has taken part in the displacement from socioeconomic redistribution to cultural identity recognition. Doing so, we also enrich the discussion on postfeminism.

\section{Material and method}

With our interest in neoliberalism as governmentality we conduct a Foucauldian discourse analysis. Discourse is defined as "practices which systematically form the object of which they speak” (Foucault, 1972a, p. 49). By practices he means text, but also other social practices - in our case for example the design of a state supported training program for women entrepreneurs. In terms of Ashcraft's (2004) categorization of four main ways of understanding discourse, this approach is "discourse as social text”. Discourse is seen as contingent and constitutive. By inclusion/exclusion it structures knowledge, and knowledge has power effects (Foucault, 1972b). The analytics of governmentality is concerned with how discourses direct the conduct of individuals or of groups (Foucault, 2003). Foucault did not prescribe any particular method; in fact, he was against this, so it is up to the analyst to devise a method suitable for the research question at hand (Foucault, 1991; Winther Jørgensen \& Phillips, 2002). We did so, and detail the analytical procedure below.

\section{Selection of material}

The Swedish government has had three programmes to support women's entrepreneurship. Between 1992 and 2002 women were offered business advice by women business advisors. In 1994, regional resource centres for women opened, and a national body was charged with being their voice towards government and parliament. This was closed in 1999, but the regional centres continued as non-profits, partly financed by the government. In 2007, an ambitious and well-funded programme called "Promoting Women's Entrepreneurship” was started, with a plethora of activities - business advice, seminars, awards, role model programmes etc. The programme was closed in 2015. Nutek, later renamed Tillväxtverket (The Swedish Agency for Economic and Regional Growth, hereafter SAERG) was commissioned by the Government to design and direct the "Promoting Women's 
Entrepreneurship” programme.

Almost all documents pertaining to the programmes were available on the websites of SAERG or the Swedish Government. A few early texts were only published as books or reports and were retrieved from the public library. We retrieved a total of 188 documents in January 2014, and in 2016 we added 12 texts that were issued after the initial search. In total, we had 200 documents with 4,338 pages of text. The documents were organized in an excelfile according to type of document. For each text, we noted the issue date, author, type, number of pages and main content. If applicable, we made notes of any arguments or policy rationales present in the texts. The texts were in Swedish, and quotations presented here were translated by the authors and checked by a professional translator. Table 1 gives an overview of the entire material, that was considered for subsequent analysis. 


\begin{tabular}{|l|l|l|l|}
\hline Document type & $\begin{array}{l}\text { No. } \\
\text { of } \\
\text { texts }\end{array}$ & $\begin{array}{l}\text { Average } \\
\text { no. of } \\
\text { pages }\end{array}$ & Author or sender \\
\hline Text in preparation for 1994 proposition & 1 & 77 & The Swedish Agency for sparsely populated areas \\
\hline Motion to the parliament & 1 & 2 & The Swedish Parliament \\
\hline Parliament debate, transcribed & 1 & 154 & The Swedish Parliament \\
\hline Propositions, PM, Reports & 4 & 60 & The Swedish Government \\
\hline Government decisions & 6 & 11 & The Swedish Government \\
\hline Texts on the regional resource centers & 6 & 18 & National and regional resource centers \\
\hline Action plans, strategies & 7 & 26 & SAERG or county level government \\
\hline News, invitations & 46 & 4 & SAERG \\
\hline Calls, criteria, rules and regulations & 16 & 5 & SAERG \\
\hline Presentations of local program activities & 37 & 6 & SAERG \\
\hline Fact sheets, statistics & 16 & 18 & SAERG \\
\hline Pilot studies/evaluations & 21 & 45 & SAERG/commissioned consultants/researchers \\
\hline Evaluations, program reports & 34 & 51 & SAERG/commissioned consultants/researchers \\
\hline
\end{tabular}

We read all the documents carefully, to assess the extent to which they contained information relevant for our research questions. We omitted texts that had very little information, such as statistics, lists of activities, or short documents with funding decisions without any motivation statements. We further omitted duplicates, such as county level reports following an identical template. Among the remaining documents, we aimed for a selection that represented the development and argumentation for the programmes over time. This resulted in 43 documents relevant for the study. Each document was coded with WEP (Women's Entrepreneurship Policy), year published (e.g. WEP01 for 2001) and a letter if there was more than one that year (e.g. WEP01c). The selected documents are detailed in Table 2.

Table 2: Policy material analysed in Step 2

\begin{tabular}{|c|c|c|c|}
\hline Id. & Date issued & Title /Type & Pages \\
\hline WEP94a & $\begin{array}{l}25 \text { March } \\
1994\end{array}$ & "The other side of the coin", Government proposition 1993/94:140 & 44 \\
\hline WEP94b & $\begin{array}{l}30 \text { May } \\
1994\end{array}$ & $\begin{array}{l}\text { Parliamentary debate concerning proposition about regional resource } \\
\text { centres }\end{array}$ & 154 \\
\hline WEP95a & 1995 & $\begin{array}{l}\text { "Money or life: perspectives on women’s entrepreneurship”, Nutek } \\
\text { B:1995:3. }\end{array}$ & 257 \\
\hline WEP01a & 2001-02 & $\begin{array}{l}\text { "To promote industry development: a future-oriented evaluation of } \\
\text { business counselling for women”, Johann Packendorff, Nutek R2001:3 }\end{array}$ & 59 \\
\hline WEP01b & $\begin{array}{l}27 \\
\text { September } \\
2001\end{array}$ & Government proposition 2001/02:4 & 151 \\
\hline WEP05a & 2005 & $\begin{array}{l}\text { Promoting women’s entrepreneurship: Evaluation for the period 2002- } \\
\text { 2004, Nutek R2005:23 }\end{array}$ & 95 \\
\hline
\end{tabular}




\begin{tabular}{|c|c|c|c|}
\hline WEP07a & $\begin{array}{l}\text { February } \\
2007\end{array}$ & $\begin{array}{l}\text { Promoting women's entrepreneurship Programme proposal, Nutek } \\
\text { infono: 021-2007 }\end{array}$ & 64 \\
\hline WEP07b & April 2007 & $\begin{array}{l}\text { Report, Part 1: Action research of activities in local and regional } \\
\text { resource centers for women, Nutek/Ramböll Info } 0088 .\end{array}$ & 36 \\
\hline WEP07c & June 2007 & $\begin{array}{l}\text { Report, Part 2: Action research of activities in local and regional } \\
\text { resource centres for women, Nutek/Ramböll Info } 0089\end{array}$ & 22 \\
\hline WEP07d & $\begin{array}{l}\text { December } \\
2007\end{array}$ & $\begin{array}{l}\text { Outcomes and governance of state initiatives of financial support from a } \\
\text { gender perspective, Nutek R 2007:34 }\end{array}$ & \\
\hline WEP08a & May 2008 & $\begin{array}{l}\text { Report, Part 3: Action research of activities in local and regional } \\
\text { resource centres for women, Nutek/Ramböll Info } 0090\end{array}$ & 40 \\
\hline WEP08b & June 2008 & $\begin{array}{l}\text { Programme plan: Support of women's entrepreneurship 2007-2009, } \\
\text { info: 021-2007, Nutek }\end{array}$ & 28 \\
\hline WEP08c & $\begin{array}{l}\text { August } \\
2008\end{array}$ & $\begin{array}{l}\text { What do we know about women’s entrepreneurship in Sweden? Part } 2 \\
\text { Years 2004-2008 Info 055-2008, SAERG }\end{array}$ & 22 \\
\hline WEP09a & $\begin{array}{l}\text { February } \\
2009\end{array}$ & $\begin{array}{l}\text { Report, Part 4: Action research of activities in local and regional } \\
\text { resource centres for women, Nutek/Ramböll Info } 0091\end{array}$ & 18 \\
\hline WEP09b & $\begin{array}{l}\text { February } \\
2009\end{array}$ & Annual Report, SAERG & 37 \\
\hline WEP09c & March 2009 & $\begin{array}{l}\text { Policy discussion SAERG, Info 084_2008 Holmquist, Barle \& } \\
\text { Wennmark }\end{array}$ & 72 \\
\hline WEP09d & April 2009 & Promoting women’s entrepreneurship 2007-2009, Info 0017, SAERG & 8 \\
\hline WEP09e & May 2009 & $\begin{array}{l}\text { Women’s entrepreneurship - make use, make possible, make visible. } \\
\text { Ambassadors for women’s entrepreneurship. Info 0028, SAERG }\end{array}$ & \\
\hline WEP09f & June 2009 & Advertisement supplement, SAERG/Almi & 28 \\
\hline WEP09g & $\begin{array}{l}\text { October } \\
2009\end{array}$ & Women's entrepreneurship in Sweden, Info 0071 SAERG & 28 \\
\hline WEP09h & $\begin{array}{l}\text { November } \\
2009\end{array}$ & $\begin{array}{l}\text { Final report: Action research of activities in local and regional resource } \\
\text { centre for women, SAERG Info } 0039\end{array}$ & 100 \\
\hline WEP09i & May 2009 & $\begin{array}{l}\text { Take advantage of the entrepreneurial drive - invite an entrepreneur } \\
\text { Female Entrepreneurship Ambassadors of the Government. Info 0026, } \\
\text { SAERG }\end{array}$ & 17 \\
\hline WEP10a & 2010 & $\begin{array}{l}\text { "Straw Hats \& Batteries”: A book about women’s entrepreneurship now } \\
\text { and then, SAERG / Centre for History of Industry }\end{array}$ & 198 \\
\hline WEP10b & $\begin{array}{l}\text { January } \\
2010\end{array}$ & Newsletter TEMPO, SAERG & 16 \\
\hline WEP10c & March 2010 & $\begin{array}{l}\text { "More women run and develop businesses” Report on results 2007-2009 } \\
\text { Promoting Women’s Entrepreneurship, Info 0140, SAERG }\end{array}$ & 8 \\
\hline WEP10d & $\begin{array}{l}\text { October } \\
2010\end{array}$ & $\begin{array}{l}\text { Business development leads to growth - examples from } 21 \text { countries, } \\
\text { Info 0217, SAERG }\end{array}$ & 60 \\
\hline WEP11a & March 2011 & Innovation and Gender, Info 0229. SAERG/Vinnova & 98 \\
\hline WEP11b & $\begin{array}{l}3 \text { March } \\
2011\end{array}$ & $\begin{array}{l}\text { Government decision on Programme to support women’s } \\
\text { entrepreneurship }\end{array}$ & 8 \\
\hline WEP12a & March 2012 & $\begin{array}{l}\text { Report "Made-up super heroine or smiling ordinary business woman?" } \\
\text { Info } 0416\end{array}$ & 44 \\
\hline WEP13a & $\begin{array}{l}\text { September } \\
2013\end{array}$ & $\begin{array}{l}\text { Vision: Sustainable growth: How can women’s entrepreneurship be } \\
\text { integrated in growth? Info 0523, SAERG }\end{array}$ & 80 \\
\hline WEP13b & 2013 & $\begin{array}{l}\text { How can the company support become more equal? Report from } \\
\text { government decision N 2012/1368, Info 0151, SAERG }\end{array}$ & \\
\hline WEP14a & 2014 & Ambassadors for women's entrepreneurship, info 0585, SAERG & \\
\hline
\end{tabular}




\begin{tabular}{|l|l|l|l|} 
WEP14b & $\begin{array}{l}\text { December } \\
2014\end{array}$ & $\begin{array}{l}\text { What to do: Guide for gender mainstreaming in regional projects. Info } \\
\text { 0550, SAERG }\end{array}$ & \\
\hline WEP15a & $\begin{array}{l}\text { February } \\
2015\end{array}$ & Diversity in business. Conditions of businesses 2014. Info 0594, SAERG & 32 \\
\hline WEP15b & March 2015 & $\begin{array}{l}\text { Evaluation of seven pilot projects. Lessons from Gender Mainstreaming } \\
\text { of business promotion activities. Final report. Info 0597, SAERG }\end{array}$ & 50 \\
\hline WEP15c & March 2015 & Research report, SAERG / Katarina Pettersson & 78 \\
\hline WEP15d & March 2015 & $\begin{array}{l}\text { Take the lead: Lessons from enhancement of skills for business } \\
\text { promotion actors. Final report, info 0598, SAERG }\end{array}$ & 66 \\
\hline WEP15e & April 2015 & Strategy proposal, SAERG & 27 \\
\hline WEP15f & April 2015 & Strategy - business promotion on equal terms SAERG & $\mathbf{4 8}$ \\
\hline WEP15g & $\begin{array}{l}15 \text { April } \\
2015\end{array}$ & $\begin{array}{l}\text { Final report: Support of women's entrepreneurship 2011-2014 dnr 012- } \\
\text { 2011-1068 Golden Rules of Leadership 2013-2014, dnr 3.1.7-2013-2707 }\end{array}$ & 63 \\
\hline WEP15h & April 2015 & $\begin{array}{l}\text { 25 years with women's entrepreneurship: From invisible to driving force } \\
\text { of growth, info 0686, SAERG }\end{array}$ & 164 \\
\hline WEP15i & April 2015 & $\begin{array}{l}\text { Under the surface. How is the talking and who gets the money? } \\
\text { Info 0587, SAERG }\end{array}$ & 58 \\
\hline WEP15j & May 2015 & $\begin{array}{l}\text { 8 years with women's entrepreneurship. Support of women's } \\
\text { entrepreneurship - results and lessons 2007 - 2014 }\end{array}$ & 30 \\
\hline
\end{tabular}

\section{Analytical steps}

In the next step, we read the 43 documents, paying attention to general shifts and displacements by asking questions such as: What is the stated aim? How are women constructed as entrepreneur /entrepreneurial? How is gender in/equality to be addressed through policy? This analysis demonstrated a clear change over time. This part of the analysis involved a discussion among the authors of their readings, resulting in the identification of three thematic areas, in which general displacements were observed:

1. the role of women's entrepreneurship

2. the function of the state and the market

3. conceptions of feminism.

Having identified the three areas, or discursive objects if you will, we then selected four key documents that formed the basis for the third step in our analysis: a fine-grained analysis of WEP discourses guided by Fraser, followed by an identification of discursive displacements over time in the three areas.

The four documents were selected because i) they informed policy or programme design; ii) they contained explicit policy arguments; and iii) they reflected the identified changes over time. The first was a text from 1993, commissioned by the Swedish government, which suggested the establishment of the Resource Centres for Women (WEP94a). The second text was a programme proposal for the Promoting Women's Entrepreneurship programme issued in 2007 (WEP07a). The third text was the programme plan for the same programme, issued in 
2008 (WEP08b). The final text was the National Strategy for Business Promotion on Equal Terms, issued in 2015. (WEP15f).

Based on our reading of Fraser, two sets of question were constructed to guide us in the reading of the four key documents:

1. What identities are recognized? What is the argument for recognizing them? How can policy enhance the recognition that is sought for?

2. Is economic, or other, imparity with men mentioned? How is women's entrepreneurship seen to take part in processes of economic, or other, redistribution?

We marked all instances related to recognition with yellow and all questions related to redistribution with green, paying attention not only to what was written, but also to silences and ambivalences. The findings were subsequently inserted in a table, which made it possible to follow how different issues were emphasized over time. See Table 3 for snippets from this analysis. 
Table 3. Snippets from third step fine-grained analysis

\begin{tabular}{|c|c|c|}
\hline Document & Expressions of recognition & Expressions of redistribution \\
\hline WEP94a & $\begin{array}{l}\text { A comparison between men and women } \\
\text { leads almost inevitably to women being } \\
\text { compared with men. [...] A miserable } \\
\text { kind of situation is described, with } \\
\text { women portrayed as a group who are } \\
\text { "not good enough" [...] There is thus a } \\
\text { need for a perspective through which } \\
\text { women's lives - women's culture - is } \\
\text { made visible and which starts with } \\
\text { women themselves and does not make } \\
\text { them some kind of inferior man. (pp. 21- } \\
\text { 22). }\end{array}$ & $\begin{array}{l}\text { "...the duty of regional politics to create } \\
\text { conditions for an equitable distribution o } \\
\text { the production/entrepreneurship across } \\
\text { different regions must be matched by it } \\
\text { treating people’s lives and welfare with } \\
\text { the same care. Every coin has two sides." } \\
\text { (p. 10) } \\
\text { "..women are demanding a bigger share } \\
\text { of the economic resources and power in } \\
\text { society. Studies and research reports } \\
\text { indicate unequivocally that the } \\
\text { distribution is still skewed." (p. 56) }\end{array}$ \\
\hline WEP07a & $\begin{array}{l}\text { A starting point for promoting women's } \\
\text { entrepreneurship is that women are } \\
\text { under-represented among both all } \\
\text { entrepreneurs and new business owners. } \\
\text { (p. 13) }\end{array}$ & $\begin{array}{l}\text { The sub-programme aims to make } \\
\text { financing more accessible for } \\
\text { entrepreneurial women. It highlights the } \\
\text { demand for small loans and the financing } \\
\text { situation for small business owners. }\end{array}$ \\
\hline WEP08b & $\begin{array}{l}\text { The programme's activities also include } \\
\text { presentation of role models and ways of } \\
\text { making women's entrepreneurship } \\
\text { visible, as well as spreading knowledge } \\
\text { about women's entrepreneurship. Role } \\
\text { models are important to inspire and to } \\
\text { show entrepreneurship's opportunities } \\
\text { and that women exist in all industries. (p. } \\
\text { 5) }\end{array}$ & $\begin{array}{l}\text { Nutek agrees that more state financing } \\
\text { for businesses is given to men than } \\
\text { women. The uneven distribution reflects } \\
\text { the under-representation of women } \\
\text { among Sweden's business owners. But } \\
\text { the results also show that many support } \\
\text { measures are in practice often directed at } \\
\text { male-dominated industries and business } \\
\text { areas. (p. 18) }\end{array}$ \\
\hline WEP15f & $\begin{array}{l}\text { It is important to utilize every } \\
\text { individual's entrepreneurship and } \\
\text { innovative powers - a diversity of } \\
\text { entrepreneurs, entrepreneurship and } \\
\text { business forms contributes to renewal in } \\
\text { industry. } \\
\text { Diversity contributes to a more innova- } \\
\text { tive climate, which in turn creates the } \\
\text { conditions for sustainable growth and } \\
\text { development. (p. } 44 \text { ) }\end{array}$ & $\begin{array}{l}\text { The starting point is that developing } \\
\text { equitable conditions within the system } \\
\text { that promotes entrepreneurship } \\
\text { contributes to sustainable growth and } \\
\text { increased competitiveness in companies } \\
\text { and regions. } \\
\text {... with a more equitable distribution of } \\
\text { resources to innovations and clusters, } \\
\text { innovations can be developed in more } \\
\text { sectors of the labour market, thereby } \\
\text { strengthening the climate for innovation. } \\
\text { (p. 44) }\end{array}$ \\
\hline
\end{tabular}

The findings from the third step were again discussed among the authors. Our joint analysis discerned two discourses through which policy for women's entrepreneurship was constructed over time. We traced the first discourse, recognizing inequality and redistributing power to 
the start of the programme in the early 1990s. The second discourse, recognizing entrepreneurial potential emerged after the new liberal/conservative coalition government introduced a new programme for women's entrepreneurship in 2007 and is most clearly expressed in the final report from 2015.

After the detailed analysis of the four key documents, we re-read the remaining 39 texts, using the two discourses as an analytical lens. In this reading we made notes of both support for, and deviations from, the two discourses. In addition, we noted images used in the texts. This enabled us to make a richer and more dense analysis, to zoom in on historical and contextual contingencies, and to further define how the three displacements observed in the first reading were expressed in the two discourses.

We report on our results in two steps. First, we describe the two discourses. We found that one was dominant in the early period, and the other towards the end, but there was no clear date when the latter took over - it was, rather, a gradual change over time. The first discourse is thus presented as taking place "1993 and onwards", and the second "2015 and backwards". In the second part we discuss the results using Fraser's notion of displacement.

\section{Discourse 1: Recognizing inequality and redistributing power (1993 and onwards)}

The discourse of recognizing gender inequality and redistributing power, through entrepreneurship, in order to provide welfare to all citizens is principally located in the preparatory text “The other side of the coin - on regional politics' tunnel vision” (WEP94a), but can be partly discerned throughout the policy period. Following the organization of the analysis in three themes (the role of women's entrepreneurship, the function of the state and the market, and ideas of feminism), we identified this discourse as comprising the following elements: 1) entrepreneurship for women; 2) politics through government; and 3) secondwave feminism.

\section{Entrepreneurship for women}

The discourse on recognition of inequality and redistribution of power strongly opposes descriptions of women as inadequate in comparison with men, and arguments are made for scrutinizing comparisons with the rational economic and entrepreneurial man. The central argument in WEP94a was that the ideal of the entrepreneurial and economic man, which had been found to subdue human life, needed to be overthrown (WEP94a). Further, a logic where women were rewarded for following systems modelled on men, and ignoring how that reified their own subordination, had to be overthrown. Instead, women should be encouraged to develop some form of entrepreneurship - in its broadest sense - on their own terms and be given space to make visible the entrepreneurial work that they were always and already involved in. The awareness of the need to change the masculine entrepreneurship norm can be traced throughout the policy period, and also in the concluding strategy, which said to abandon the epithet of "female entrepreneurs" as it reproduced the notion that there are "real male' entrepreneurs, without the need for a prefix (WEP94a -- WEP15f). 
Being entrepreneurial was in this discourse not limited to starting a business but was also perceived as women's ability to organize collectively (WEP94a), and for project and networkbased forms of entrepreneurship that responded to communal needs (WEP95a, WEP01a, WEP07b). The concept of "lifeform" was used as it was said to acknowledge the complexity of how different tasks take place over time in an individual's life. It was stated that a foreclosure of the female world had never benefited women's claims for power and freedom. The entrepreneurial lifeform was seen to recognize women's lives and perspectives and value domestic (women's) work (WEP95a). Economic resources should be redistributed so that such a life could be lived by both men and women (WEP95a). Although entrepreneurial is understood broadly in this discourse, entrepreneurship is also coupled with business. The balanced small business lifeform, it was stated, "has luminosity" because the life pattern that can develop through that form makes it possible to combine traditional female responsibilities with independence (WEP94a, p. 28). Irrespective of whether entrepreneurship is understood narrowly (business) or broadly (organizing work /life in entrepreneurial ways) the discourse emphasizes how entrepreneurship may be used by women and for women to bring about change.

The other side of the coin required decision-makers to place the relationship between the masculine entrepreneurship norm and the position of the woman as underdog at the centre of all policy making (WEP94a). The text said that policy may otherwise invite women to reproduce their own position of underdog to the masculine entrepreneurial role model. The complexity of the discourse invites reflection and actions with regard to policy measures. What is desired are initiatives that can both change the situation for individual women (and recognize them) and at the same time change unjust gender structures (redistribute resources and power). The mutual relation between recognition and redistribution is characteristic for this discourse and recurs in a variety of ways; sometimes through problematizing 'women's entrepreneurship' (WEP95a), sometimes through applying different analytical perspectives to 'women’s entrepreneurship' (WEP01a).

Nurturing an authentic, and non-oppressive, entrepreneurial identity, is in this discourse coupled with a need to make starting a company equally accessible for women as for men. The discourse also emphasizes how entrepreneurship can be used by women to organize for women's collective and feminist action.

A politics through government

The other side of the coin stressed the need to create conditions for a more equal distribution of space, time, domestic work, professional work and resources among men and women, so they could take part in society and influence their own lives on equal terms, irrespective of where in Sweden they lived. The text was written two years before Sweden joined the EU. European integration was expected and perceived to increase the pace of structural change and add to regional imbalance. Regarding industrial transformation and urban migration, the public sector, which employed a large proportion of women, was expected to face major austerity measures. The text acknowledged that since this would affect women and men 
differently, there was a need for both reflection and action and, particularly, to focus on women's situations and lives in rural areas (WEP94a). Accordingly, the redistribution of power and resources should mean that everyone - regardless of residence or gender - would be able to partake in the production of the other side of the coin, which concerned every citizen's right to welfare. (WEP94a).

Hence, the concept of "regional politics" is crucial to this discourse, which is defined as a form of redistribution of welfare between people in different parts of the country, so all citizens may have freedom of choice, regardless of residence or gender. Connections should be made between national, regional and local levels to unravel how terms of production and economic imperatives affect people's lives (WEP95a). This was seen as a prerequisite for building regional politics on the recognition of gender and regional differences and for redistributing power and resources to secure the right to welfare for all (WEP94b). It was highlighted that women may flee rural areas for an urban life. To prevent such an exodus, regional politics must be grounded in women's own culture so that alternatives could be created to attract women to stay and make the region viable (WEP94a).

The need to bring about a change of direction - from urban to rural, from men to women must be recognized, according to WEP94a. The text described women in all types of occupations; from district nurses working for the local community to women artists. It also pointed out the need to recognize that women and men occupy different sectors of the labour market, with different conditions, and that women are most vulnerable in rural areas. The text further stressed the need to recognize the presence of both paid and unpaid work, where women take the main responsibility for the latter in the form of domestic work and parenting. It said that the underestimated 'women's work' calls for a holistic view of work that does not equate work with employment. Women should be recognized on their own terms, which "calls for a perspective through which the lives of women - the female culture - is made visible and based on women themselves without making them inferior to men" (WEP94a, p. 22). It stressed the importance of talking to women (entrepreneurs) and not about them (WEP95a, p. 13ff.).

This discourse says that the state must intervene by supporting the political voice of women and, especially, supporting women in rural areas. Combatting inequalities through political means, such as quotas, and building structures that enable women's political activity, should be a top priority for the state.

\section{Second-wave feminism}

The discourse emphasised that even if legislation against gender discrimination is in place, labour market conditions are still skewed. Work done by men and women is valued differently (WEP95a). The text pointed out that women and men do the same work, but men earn more and hold senior positions whilst women devote more time to unpaid work in the home. The text said that such unjust working conditions require a revaluation with regard to both paid and unpaid work so that time can be redistributed between work and leisure and divided more equally between women and men (WEP94a). It was further suggested that the 
ideal would be to include non-paid work in the notion of work and then redistribute work accordingly. A guiding principle for this would be to follow the women's way: "to match the efforts of the labour market in relation to children and other family members' needs" (WEP94a, p. 33). In addition, quotas were proposed to give the under-represented sex priority in recruitment processes. It was suggested that the segregated labour market constitutes a vehicle around which new initiatives for gender equality and regional development could take shape (WEP94a).

Whilst women as a group were to be recognized, it was also stressed that there is a diversity of women, emphasizing that women, like men, may have some common interests but also have differing or contradictory interests. Using the terminology in this article, recognizing women's realities must be followed by recognition of the subordination of women and the domination of men. However, women do not make up the category to be recognized. Rather, it is inequality and gendered relations that need to be recognized (WEP94a, WEP95a, WEP01a). In this vein, there is also a need to recognize masculine norms, the oppression of women, fear of the unknown and gender struggles.

The discourse uses arguments of second-wave feminism's call for social justice. Gender stereotypes need to be recognized and problematized, at the same time as women are supported to nurture their own culture and engage in political and feminist action. While the text in the documents about nurturing women's own culture and life-style may run the risk of homogenizing and essentializing women, the policy argumentation is nevertheless clearly based in a feminist standpoint perspective. In this discourse, women's positions are to be problematized, not women. So is the male entrepreneurship norm and the devaluing of domestic and care work. There is further a recognition that to change unequal structures, feminism works on two fronts: from within the state and bottom-up, providing space for women to organize.

“The other side of the coin” underlined the risk of depoliticizing equality through women's entrepreneurship policy and raised a warning against tendencies to prioritize short-term quantitative measures before long-term qualitative change (WEP94a, p. 4-5, 7). The preparatory text had a strong influence on WEP, evidenced by the fact that most of the suggestions as well as the rationales in this text were subsequently included in the government proposition (Proposition, 1993/94:140). Early policy actions included information and business advice for women, entrepreneurship with a gender perspective in higher education, and a women's entrepreneurship research programme (WEP05a). These investments paved the way for new investments, while maintaining the vision of bringing about long-term change of the gendered business landscape, guided by the vision of gender equality (WEP94b, WEP01b, WEP07a). In this discourse, both recognition and redistribution are present, and interrelated: recognition of gender and regional inequalities calls for the redistribution of entrepreneurship (from men to women), to contribute to a more democratic society. 


\section{Discourse 2: Recognizing entrepreneurial potential (2015 and backwards)}

The discourse of recognizing the entrepreneurial potential of women and 'others' to increase economic growth emerged during the last two decades and is most prevalent in the final strategy in 2015. The word 'redistribution' has almost disappeared, and recognition is no longer a matter of perceiving inequality but about recognizing the entrepreneurial potential among women and 'othered' social groups. Organizing the analysis in the three themes (the role of women's entrepreneurship, the function of the state and the market, and ideas of feminism), we identified this discourse as comprising the following elements: 1) women's entrepreneurial potential, 2) a politics through the market, and 3) postfeminism.

\section{Women's entrepreneurial potential}

In March 2015, 22 years after the publication of the "The other side of the coin", the last programme to support women's entrepreneurship was evaluated and finalized. The closing was celebrated at a national conference, at which a new national strategy called “Entrepreneurship Support on Equal Terms” was presented. This was aimed to guide policy in general for the coming five-year period 2015-2020 (WEP15e, WEP15f). The 2015 strategy "Open up", presented diversity figuratively, on the cover, in the form of a blurred collage of pictures of men and women smiling into the camera (WEP15f). The cover, together with pictures in the document, signals diversity and shows the need to include everyone, as in the photo of a man (in the spotlight) and a black woman (in the shadow) with the challenging question: "How do we reach everyone?" The strategy communicated the need to understand how diversity and equality are linked to the generation of new ideas and businesses. Young women and women with a foreign background were targeted as new and previously unrecognized groups (WEP15j). Unleashing the entrepreneurial potential among yet unrecognized social groups is seen as awakening a dormant resource to benefit both the individual herself and the nation (WEP10b).

The majority of activities launched through the policy programmes focused on training women (WEP15b), in spite of the fact that women were found to be better educated than men (WEP15b; WEP09g). Women and others were also encouraged to respond to the imperative of 'becoming more'. Women entrepreneurs should not only become more in quantitative measures, but were asked to improve themselves by being a role-model and engage and educate others to take the step (WEP10c). Some of the women who took part in the programme stated a need to believe in themselves, to follow their dreams, to stay strong, yet challenge themselves to move on (WEP14a, p. 9 ff.). Entrepreneurship is thus not only directed towards business, but also appropriated for its wider meaning, including seeking out the "occupations and educational programmes they want without being hampered by structural barriers and discrimination” (WEP15f, p. 45).

Women are still the target group in the discourse on recognition, but diversity in terms of ethnicity, age, profession etc. is now added with the imperative to better communicate the entrepreneurship option to all, and especially to those who are underrepresented as business owners. The discourse thus targets the diversity of woman, to recognize her slumbering 
entrepreneurial potential to mobilize her willingness to further strengthen her skills and competences so that she can shape her life in a better way.

\section{A politics through the market}

In the initial foreword to the final strategy, the Director-General emphasized the need for "business promotion organisations [to] offer support on equal terms to women as well as men, regardless of ethnic background and age, as [this is] a matter of democracy and equity" (WEP15f, p. 7). Further, the foreword declared: "When a range of different ideas are utilised, and businesses within a broad range of industries have the opportunity to blossom and grow, the foundations for economic renewal and dynamics are strengthened. A great variety of businesses and entrepreneurs is good for growth. So it is important that the community's resources for business promotion are open and available on equal terms to all.” (WEP15f, p. 7). Policy actors were to "see opportunities" in equality and diversity (WEP15d), since "the diversity of entrepreneurs, businesses and business forms contribute to a renewal of trade and industry” (WEP15f, p. 3). Recognition runs through the strategy, which is described as a winwin strategy where both 'aware' and 'blind-folded' actors in the support system, together with as yet unrecognized entrepreneurial actors, become mutually supportive of each other. Rather than a case of discrimination or unfair distribution of power and resources, injustice is seen as a matter of industry variation and market conditions (WEP15f, p. 9).

The programmes that women's entrepreneurship policy initiated were said to have presented individuals with opportunities for personal growth and they were also seen as a driving force of economic growth (WEP15h), since these initiatives lead to innovations and new markets, which secures sustainable growth of businesses, regions and nations (WEP13a). Occasionally this logic is reversed by making gender equality the prerequisite for innovations that break with existing social orders (WEP11a). But overall, the flow from developing individuals to the growth of markets offers a smooth road ahead without the tensions, struggles or conflicts that were present in the earlier discourse on recognition and redistribution.

The broad approach to women's entrepreneurship visible in 2007 which created conditions for both recognition and redistribution to inform policy measures is no longer present in policy discourse. When the programme was launched, the six suggested sub-programmes ${ }^{1}$ were boiled down to four, moving “Analysis and research” to another governmental agency and removing "Regulations" altogether (WEP09d). In the evaluation of the 2007-2009 period (WEP10c) the sub-programme names were no longer used; instead the following three imperatives structured the results: "Make use" (for women who are entrepreneurs); "Make possible" (for women now and in the future to start and run a business); and "Make visible" (Role models and Ambassadors) (WEP10c, p. 2, also emphasised in WEP09d, WEP09e, WEP09f).

Despite emphasising recognition, the programme still reported on redistribution. A notable

\footnotetext{
${ }^{1}$ The 2007-2009 plan contained an ambitious proposal for six sub-programmes: 1) Information, advice and business development, 2) Policy actions in other national programmes, 3) Funding, 4) Regulations, 5) Attitudes and role models, and 6) Analysis and research (WEP07A, WEP08b, WEP09b).
} 
study found that most of the government's financial support to Swedish businesses actually went to men. The first report showed that support was, in practice, directed at male-dominated industries and sectors (WEP07d). The 2013 report showed that during the period 2009-2011, men's businesses received SEK 1,431 million (92.5 per cent), while women were granted SEK 116 million (7.5 per cent) (WEP13b). The average amount applied for and granted was also significantly lower for companies run by women than for those run by men. Both reports noted that more women run businesses with a local or regional market that, for reasons of fair competition, were largely excluded from financial business support. This implies that the 'general' financial support is already earmarked for men. But it is not labelled as "support for men's entrepreneurship". Its gendering is made invisible - it is simply understood as 'necessary' for the general good. So, redistribution is left out of the discourse. Instead, gender equality and diversity are turned into a recipe where groups suffering from misrecognition are perceived as an untapped resource that could bring about a more diverse stock of enterprises and entrepreneurs, in turn creating sustainable economic growth (WEP13a, WEP15i). The onus to bring about a more equal and inclusive society, through business ownership, is placed on individual women. Women's entrepreneurship policy became economic policy, but kept its social and gender equality façade.

\section{Postfeminism}

A central element of the policy programme initiatives from 2007 were the "women ambassadors" nominated by the government, whose mission was to make entrepreneurial women more visible, to offer young women role models, to stimulate general interest in entrepreneurship and to disseminate knowledge about what it meant to start, operate and develop a business (WEP09e, 5-6). Women ambassadors have shared their stories and experiences with the general public, and in particular with pupils in schools, but also with NGOs, state agencies and other organizations (WEP09i, WEP14a). One woman gave the following reason for becoming an ambassador: "I want to inspire and incite enthusiasm in people to use their full potential, to dare to grow. I also believe that it is important not to act more important than anybody else, otherwise it would be wrong. I want to convey my knowledge and emphasize the strength of others, a strength that they already have inside them" (WEP09g, p. 9).

To qualify as an ambassador and role model for others, the programme stressed the importance of individual women viewing the path of entrepreneurship as a choice they made as a result of their own situation and interests. The woman entrepreneur was to become the role model in her meeting with the audience; and the listeners were to discover their slumbering entrepreneurial potential. Ironically, however, each ambassador was told to represent herself as a female entrepreneur (WEP09e), whereby she instantly and unintentionally turns into an 'other' in comparison to the masculine norm.

The promotion of women ambassadors was critically assessed by Nilsson (2010). Using the metaphor of "Embassy" she problematized that women ambassadors were positioned as p(e)ace-makers, that the women were seen to encompass an "ace-maker capability" in spotting 'aces', that new entrepreneurial talents were to be developed and that the pace- 
makers should keep on going in a general ambition to mobilize the male-gendered entrepreneurship discourse, and as the peace-maker was seen as having to mediate requirements from different ideologies (Nilsson 2010, p. $31 \mathrm{ff}$.). To add to this criticism, we find that the Ambassador programme positioned women's entrepreneurship as a voluntary task, since they did not receive any compensation for their duties of this Embassy (WEP09e, WEP15c).

This discourse describes women as 'having potential' but, paradoxically, also as 'lacking' and in need of working on herself to unleash her potential. The gaze is turned from masculine norms and other prevailing unjust structures to the woman herself. Through techniques of self-surveillance, choice and empowerment she is now spurred to turn gender differences and obstacles into business ideas. This requires a close examination of herself, and other women, to engage in a makeover of women so that they can better understand and make use of their potential.

\section{Discussion: Three discursive displacements over a 20-year period}

A discursive shift has occurred during the studied period. The emphasis of the early efforts on the need to recognize inequality and redistribute resources and power to give all women a political voice has, over time, tipped over to a focus on recognizing entrepreneurial potential to strengthen the innovative capacity of Sweden and contribute to economic growth. The shift has occurred through three discursive displacements: 1) the displacement from entrepreneurship for women to the recognition of women's entrepreneurial potential; 2) the displacement from a politics through government to a politics through the market; and 3) the displacement from second-wave feminism to postfeminism (see Table 4). 
Table 4. Three discursive displacements.

Thematic areas

Displacements

Discourse 1: Recognizing

Discourse 2: Recognizing

inequality and

entrepreneurial potential

redistributing power

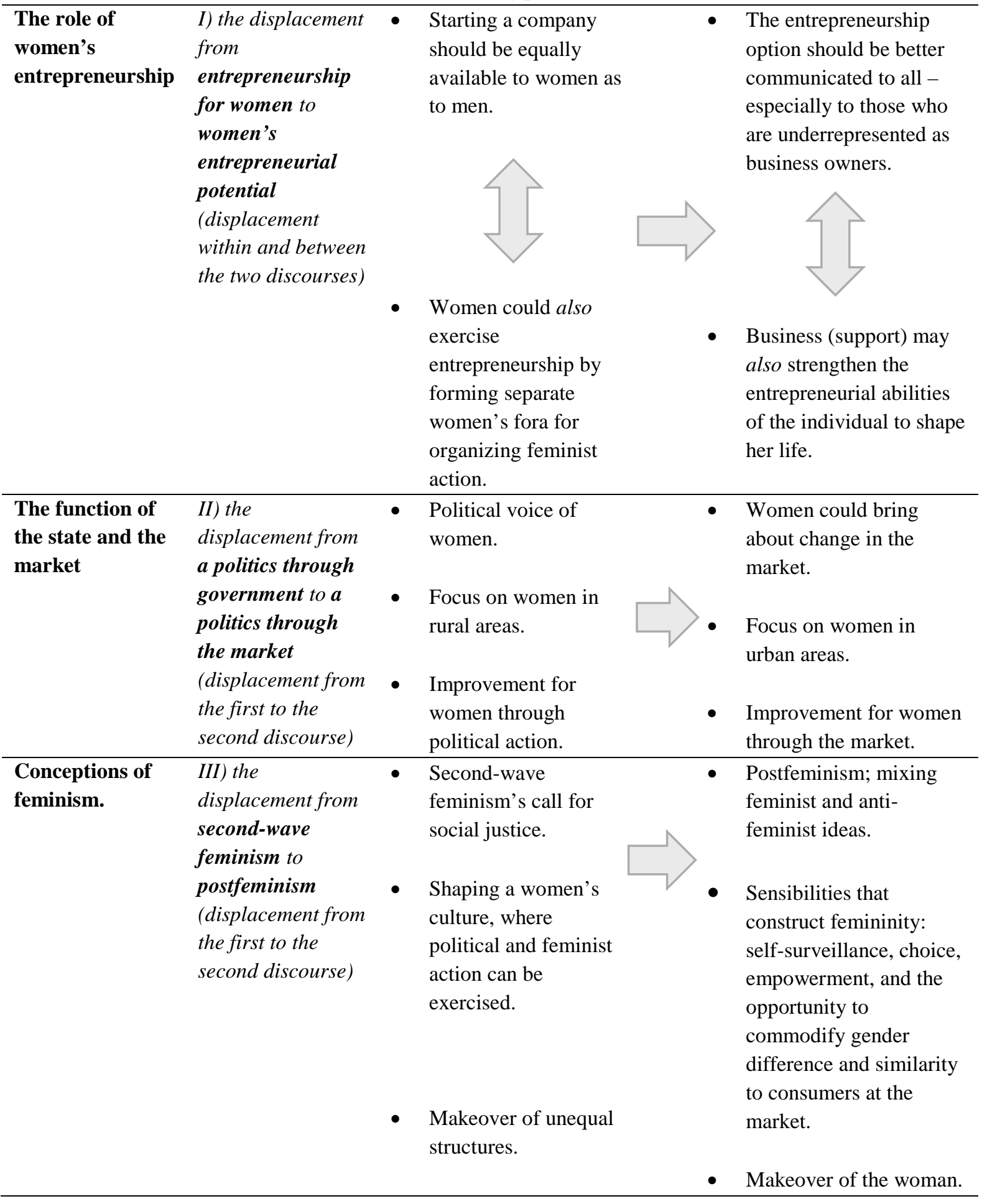




\section{Displacement I - from entrepreneurship for women to women's entrepreneurial potential}

concerns a move away from promoting small business for the benefit of women, to a broader understanding of entrepreneurship, underpinned by the entrepreneurialisation of identities (cf. Berglund, Lindgren, \& Packendorff, 2017; Lewis, 2014). Unlike displacements II and III, this displacement occurs within the discourses as well as between them. It shows variation in how "entrepreneurship" is used - it refers both to the entrepreneur as a small business owner and to the broader view of entrepreneurship as both collective and individual action. Thus, in both discourses entrepreneurship transgresses the idea of starting a business and is aligned with how life as an entrepreneurial project need be figured out and processed (Rose, 1993).

In the first discourse on redistribution, the small business entrepreneur occurs concurrently with aims of creating room for women to organize collectively in entrepreneurial ways to make their voices, as well as their interests and questions, heard. Entrepreneurship is described as a means (small businesses and non-profit organizations) through which feminist action (organizing and distributing welfare to all citizens on women's terms) can take place. In the subsequent discourse, which shifts to recognizing potential, women are provided with a clearer route to be(come) a business owner who can develop her entrepreneurial potential through business, various training programmes and by offering her expertise to others. Nonetheless, starting a business might be one result, as becoming (more) entrepreneurial is also seen as a prerequisite for making a life for oneself.

The move from the entrepreneur as the business owner to the entrepreneurial human being is made possible by making the entrepreneur into a "measuring stick" for human activity (Bröckling, 2015). The entrepreneurial being is put on a pedestal, to be criticized and moulded into new versions, but remains something to aspire to (Jones \& Spicer, 2005). It invokes a logic of comparison and competition - one can never be "good enough". If anything recurs over the two decades, it is the criticism of entrepreneurship as modelled upon men. In the first discourse, this criticism is formulated as a wish to reconstruct life as such from women's entrepreneurial experiences, and thus to reconstruct the masculine entrepreneurship discourse and its political effects. In the subsequent discourse, critique is still present but has assumed a new shape. Women and other underrepresented groups must now challenge the masculine norm by developing their potential to become as successful entrepreneurs as their male counterparts - or better. But the idea of reconfiguring entrepreneurship based on the experiences or life forms of women is gone.

Although this displacement occurs within both discourses there is, over time, an increasing emphasis on the individual to become entrepreneurial - not just start a business, but make all facets of life entrepreneurial. In the first discourse, lifeforms took a collective shape, while in the latter discourse the entrepreneurial project was individualised. Individual potentiality is central to the programme. It can be understood as an individual's desire to become 'more' of what one already is - more entrepreneurial, more innovative (cf. Costea, Amiridis, \& Crump, 2012). When such a desire is mobilized, it brings about a culture where it is increasingly difficult to be content with oneself (Scharff, 2016). Critique is turned inward, instead of outward, to unjust structures. The political dimension is neglected, human limits are 
suppressed and it becomes difficult to identify collectively formed alternatives (Berglund, 2013).

The displacement between the two discourses - from a collective understanding of entrepreneurial action (i.e. entrepreneurship for women) to an expectation of individual women to make use of their entrepreneurial potential has power effects. It shows how policy for women's entrepreneurship has come to put an even greater burden on individual women to find entrepreneurial ways to make ends meet with regard to both working life and family life, while collective solutions have become silent. Through WEP, women have been provided with the opportunity, but also the imperative, to give their life an entrepreneurial form (Lemke, 2001).

\section{Displacement II - from a politics through government to a politics through the market} concerns a shift with regard to where the problem posed by policy should be solved. The first policy discourse stressed how entrepreneurship can become a means for women to make their voices heard to fight injustice and strengthen democracy. The responsibility of the state to reform unjust, unequal structures and regulations, via policy, has, however, in the second discourse been replaced by a market logic which instead stresses privatization, competition and commercial revenue generation (Fraser, 2000). In other words, the solution to the problem of inequality has become privatized.

In the market, structural change becomes a matter of changing the narrow-minded cultures of particular business sectors and opening up for recognizing unaddressed consumer needs. The expectation is that when women and other underrepresented groups enter a marketplace in which outmoded patriarchal views of entrepreneurship are no longer insurmountable obstacles, women will create new markets. They are to bring new innovations based on their experiences and perspectives to the marketplace and supply goods and services to fulfil as yet unmet needs. The second discourse holds a silent understanding of markets as places where calls for cultural recognition and economic distribution can be met more effectively than by government intervention. As entrepreneurial individuals take matters into their own hands, life can be improved for all, without political action, resistance and conflicts.

In this displacement, issues of equality and democracy have been stretched and bent to fit the overall economic growth discourse (Lombardo et al., 2009), so that they can be dealt with at the market place rather than through politics (Lemke, 2001). Governing takes the form of a technical activity rather than political action. Experts within various professions who were previously employed by the state, including "femocrats" (feminists employed by the government and working for women's rights through state action) become obsolete (Ahl et al., 2016), and are replaced with 'entrepreneurial professionals’ (Rose, 1993). Women’s criticism of the masculine norm and call for structural change in the first discourse turned against them - the onus is now on individual women to work for better terms, but through entrepreneurship, in market conditions. The entrepreneurial subject enters the stage and moves the political subject to the background. 
Displacement III - from second-wave feminism to postfeminism concerns a shift from the first discourse, where feminism's call for social justice was coupled with entrepreneurship, collective action and a politics of redistribution, to the subsequent postfeminist discourse which mixes feminist ideas with counterproductive anti-feminist ideas (McRobbie, 2004). This involves a depoliticization of central goals of second-wave feminism (Stacey, 1990), an avoidance of a "feminist persona” (Pomerantz, Raby, \& Stefanik, 2013), and a makeover paradigm of the woman (Gill, 2007). The shift is facilitated by the expansion of the entrepreneurship discourse in which "human ability to act" is rephrased as "entrepreneurial ability”. Describing any activity as entrepreneurial legitimizes and privileges the marketbased enterprise form for social, cultural, and even activist activities. If the androcentric and male-dominated business landscape was historically something women fought against to claim their rights, it nowadays contains aspirations for social and feminist change, but through competition between individuals rather than through solidary, collective action.

The second discourse reflects postfeminist elements such as self-surveillance, choice, empowerment, and the opportunity to commodify gender difference and similarity for consumption on the market. These "technologies of the self”, or governmentality in turn propel the makeover paradigm. They include the wish to transform the woman who has not yet explored her entrepreneurial capacities into the woman entrepreneur who has begun to do so and who also tells others the story of her journey (compare Sullivan and Delaney, 2017). Business, entrepreneurship and market(ing) principles are offered as 'tools' to change one's own life and destiny, and at the same time bring about feminist change - but on market terms. Not only is a woman to go through an outer makeover, 'dressing up', so that she can compete against others to gain market shares, but as a neoliberal subject she is also to search within herself to tackle dilemmas, overcome anxiety and exhaustion, and motivate herself to keep on going and discover new facets of her potential (Scharff, 2016).

The discourse of recognizing women's entrepreneurial potential is unidirectional, subordinating other goals and visions, such as the gender equal society where resources need to be redistributed equally to maintain the welfare for all citizens promoted in the first discourse. This 'win-win' makes a sharp contrast to the former reflexive 'back and forth' discourse of recognizing inequality which also housed 'win-lose' and 'lose-lose' discussions. Apart from the wish for increasing growth, the whys and wherefores of an egalitarian society, stressed in the first discourse, have disappeared. The analysis shows the danger of focusing only on recognition - as Frazer $(2000,2013)$ pointed out, when recognition and redistribution were better integrated, it supported feminism as a collective project.

Neoliberal societies may have offered some individual women the means to free themselves from the shackles of inequality through enterprise, but their freedom is at the expense of other women, most notably the low paid care workers who make the success of the former possible. Income inequalities between women result. Women's political action has simultaneously been curtailed. With entrepreneurship comes the responsibility to free oneself from passivity, inequality, racism and unemployment, and turn into an active and economic actor who brings the excluded other into the market. This entrepreneurial activity is out of kilter with feminist 
political action as it has been known.

\section{Conclusion}

By using the analytical concepts recognition, redistribution and displacement as tools for empirical inquiry, this study showed how assumptions underlying and motivating policy for women's entrepreneurship in Sweden has changed over a 20-year period, from those of second wave feminism to those of neoliberal postfeminism. A radical feminist discourse that explicitly questioned androcentric patterns in business and society, and called for women's collective action, state interference, redistribution and structural change, was replaced by a postfeminist neoliberal discourse. It took the form of a governmentality that encouraged individual women to assume an entrepreneurial persona, start their own business, compete in the marketplace and contribute to economic growth. The second discourse held a silent understanding of markets as places where calls for cultural recognition and economic distribution can be met more effectively than through government intervention, and without political resistance and conflict.

But the promised benefits for women as a group did not materialize. The idea of making it on one's own and thereby changing structures did not work. Opportunity was not equally available to everyone - feminine-gendered, low-paid businesses were those most easily available to women, so gendered patterns in choice of occupation, influence and earnings remained the same. A reified identity for women and other 'others' was (re)created. Previous structures built to secure equality, such as public welfare services, were changed or dismantled. Thus, a postfeminist policy strongly geared towards recognition and identity politics reproduced women's subordination. The status quo remains.

The performative power found to be effective in neoliberal, postfeminist governmentality, and in the move from redistribution to recognition, is at work in the three displacements. In contrast to disciplinary power that requires 'obedience', this form of power appears as a 'kinder' version that is more 'concerned' with a woman's problems and provides her with support to change her own, as well as her fellow sister's, cumbersome situations. But by promising women 'entrepreneurial freedom' to change their lives and destinies, the neoliberal governmentality transfers responsibility from the government to the individual. It thereby obscures, or renders structural problems/solutions, and collective feminist action, irrelevant. Instead, it makes women turn critique inwards, against themselves, to improve themselves and their position in the market place through competition rather than through cooperation. The subject position "political activist" is not available in this discourse.

The benefits for the individual (personal development) are entwined with the group (opportunities for collective social change), which makes resistance difficult, but not impossible. But it requires deliberate action, and a language to be able to talk about it. The study provides academics, policy-makers and women entrepreneurs with a language for such discussion. The analysis of the two discourses and the displacements over time shows how the neoliberal ideal of the self-fulfilling, entrepreneurial individual is a masculine gendered ideal constituted through historically contingent ideas of economic rationality, freedom, and 
individualism, and it shows how this idea is an obstacle for gender equality. By doing so, it offers tools for the formulation of a feminist 'counter-discourse', or a "post-postfeminist" discourse if you will, that may help challenge contemporary theorization and practice of women's entrepreneurship.

\section{Contributions and further research}

Through an analysis of changes in women's entrepreneurship policy over time, the study shows the ubiquity of the postfeminist discourse: it is present not only in media and culture, or in organizations, but it is at the heart of policy formulation. The analysis demonstrates the centrality of "entrepreneurship" to the neoliberal, postfeminist discourse. It shows how entrepreneurship has been reformulated from starting an organization, to conducting one's entire life in entrepreneurial forms, thereby governing the conduct of individuals, i.e it demonstrates how postfeminism works as a governmentality. It further shows that the consequences of such conduct may not be to the benefit of women - the evidence suggest that the promised economic outcomes have not materialized, inequalities between women have increased, and women's collective, political activism has been rendered irrelevant. Even worse, the postfeminist discourse puts the blame for this on individuals rather than structures.

The article makes a theoretical contribution to studies of postfeminism by adding Fraser's theories of how recognition has displaced redistribution to the discussion. Our formulation of three discursive displacements in policy - from entrepreneurship for women to women's entrepreneurial potential; from a politics through government to a politics through the market; and from second-wave feminism to postfeminism - adds nuance and depth to the understanding of how postfeminism has displaced feminism. The three displacements may be used as a starting point in future studies. The article further makes a methodological contribution by turning Fraser's framework into a tool for empirical inquiry that may be used in future research projects. Examples may be studies of any other written long-term material, such as how women are presented in company reports, in media, in management or in organization studies textbooks used in business schools, and so on. We also encourage using the identified discursive shifts to study contemporary expressions of women's entrepreneurship, in practice as well as in policy. Finally, we suggest that taking part of the results from the policy analysis presented in this article is important for any researcher who is also engaged in assisting policy makers.

\section{References}

Ahl, H. (2006). Why research on women entrepreneurs needs new directions. Entrepreneurship Theory and Practice, 30(5), 595-621.

Ahl, H., Berglund, K., Pettersson, K., \& Tillmar, M. (2016). From feminism to FemInc. ism: On the uneasy relationship between feminism, entrepreneurship and the Nordic welfare state. International Entrepreneurship and Management Journal, 12(2), 369392. 
Ahl, H., \& Marlow, S. (2012). Exploring the dynamics of gender, feminism and entrepreneurship: advancing debate to escape a dead end? . Organization, 19(5), 543562.

Ahl, H., \& Marlow, S. (2017). Sisters doing it for themselves? A Postfeminist critique of Entrepreneurship. Paper presented at the Academy of Management Proceedings.

Ahl, H., \& Nelson, T. (2015). How policy positions women entrepreneurs: A comparative analysis of state discourse in Sweden and the United States. Journal of Business Venturing, 30(2), 273-291.

Alcoff, L. M. (2007). Fraser on redistribution, recognition, and identity. European Journal of Political Theory, 6(3), 255-265.

APEC. (2011). Declaration. High level policy dialogue on women and the economy. San Francisco, California. September 16, 2011. Retrieved from https://20092017.state.gov/p/eap/rls/ot/2011/172651.htm

Arum, R., \& Müller, W. (Eds.). (2004). The reemergence of self-employment. A comparative study of self-employment dynamics and social inequality. Princeton: Princeton University Press.

Ashcraft, K. L. (2004). Gender, discourse and organization: framing a shifting relationship. In D. Grant, C. Hardy, C. Oswick, \& L. Putnam (Eds.), The Sage handbook of organizational discourse (pp. 275-298). London: Sage.

Baccaro, L., \& Howell, C. (2011). A common neoliberal trajectory: The transformation of industrial relations in advanced capitalism. Politics \& Society, 39(4), 521-563.

Berglund, K. (2013). Fighting against all odds: Entrepreneurship education as employability training. Ephemera, 13(4), 717-735.

Berglund, K., \& Granat Thorslund, J. (2012). Innovative policies? Entrepreneurship and innovation policy from a gender perspective. In S. Andersson, K. Berglund, E. Gunnarsson, \& E. Sundin (Eds.), Promoting Innovation: Policies, practices and procedure. Stockholm: Vinnova.

Berglund, K., Lindgren, M., \& Packendorff, J. (2017). Responsibilising the next generation: Fostering the enterprising self through de-mobilising gender. Organization, 1350508417697379.

Bertaux, N., \& Crable, E. (2007). Learning about women. economic development, entrepreneurship and the environment in India: A case study. Journal of Developmental Entrepreneurship, 12(04), 467-478.

Botha, M., Nieman, G., \& van Vuuren, J. (2006). Enhancing female entrepreneurship by enabling access to skills. The International Entrepreneurship and Management Journal, 2(4), 479-493.

Braedley, S., \& Luxton, M. (Eds.). (2010). Neoliberalism and everyday life: McGill-Queen's Press-MQUP.

Brown, W. (2003). Neo-liberalism and the End of Liberal Democracy. Theory \& Event, 7(1).

Bröckling, U. (2005). Gendering the enterprising self: Subjectification programs and gender differences in guides to success. Distinktion: Scandinavian journal of social theory, $6(2), 7-25$.

Bröckling, U. (2015). The entrepreneurial self: Fabricating a new type of subject: Sage.

Budig, M. J. (2006a). Gender, self-employment and earnings. The interlocking structures of family and professional status. Gender \& Society, 20(6), 725-753.

Budig, M. J. (2006b). Intersections on the road to self-employment: gender, family and occupational class. Social Forces, 84(4), 2223-2239.

Budig, M. J., Misra, J., \& Boeckmann, I. (2012). The motherhood penalty in cross-national perspective: the importance of work-family policies and cultural attitudes. Social Politics, 19(2), 163-193. 
Butler, J. (1997). Merely Cultural. Social Text, 52(53), 265-277.

Butler, J. (2013). For white girls only?: postfeminism and the politics of inclusion. Feminist Formations, 25(1), 35-58.

Costea, B., Amiridis, K., \& Crump, N. (2012). Graduate employability and the principle of potentiality: An aspect of the ethics of HRM. Journal of Business Ethics, 111(1), 2536.

Dean, M. (1999). Governmentality. London: Sage.

du Gay, P. (2004). Against Enterprise (but not against 'enterprise’ for that would be silly) Organization, 11(1), 37-57.

Esping-Andersen, G. (1990). The three worlds of welfare capitalism. Cambridge, UK: Polity Press.

Esping-Andersen, G. (2009). The incomplete revolution. Adapting to women's new roles. Cambridge, UK: Polity Press.

Foss, L., Henry, C., \& Ahl, H. (2014). Review of Policy and Practice Implications in Gender and Entrepreneurship Research. Paper presented at the Diana International Research Conference 2014 http://www. esbri. se/june2014/diana. asp.

Foucault, M. (1972a). The Archeology of Knowledge. London: Tavistock.

Foucault, M. (1972b). The Discourse on Language (L'ordre du discourse). In The archaeology of knowledge \& The discourse on language (pp. 215-237). New York: Pantheon Books.

Foucault, M. (1991). Questions of Method. In G. Burchell, C. Gordon, \& P. Miller (Eds.), The Foucault Effect. Chicago: The University of Chicago Press.

Foucault, M. (2003). Governmentality. In P. Rabinow \& N. Rose (Eds.), The essential Foucault: Selections from the essential works of Foucault 1954-1984 (pp. 126-144). New York: The New Press.

Fraser, N. (1995). From Redistribution to Recognition? Dilemmas of Justice in a PostSocialist Age New Left Review, 212, 68-93.

Fraser, N. (1997a). Heterosexism, misrecognition, and capitalism: A response to Judith Butler. Social Text(52/53), 279-289.

Fraser, N. (1997b). Justice interuptus: Critical reflections on the "Postsocialist" Condition. London: Routledge.

Fraser, N. (2000). Rethinking recognition. New Left Review, 3, 107-120.

Gavanas, A. (2013). Rena hem på smutsiga villkor? Hushållstjänster i den globala arbetsfördelningen. In A. Gavanas \& C. Calleman (Eds.), Rena hem på smutsiga villkor? Hushållstjänster, migration och globalisering (pp. 7-26). Göteborg: Makadam.

Gill, R. (2007). Postfeminist media culture Elements of a sensibility. European journal of cultural studies, 10(2), 147-166.

Gill, R. (2008). Culture and subjectivity in neoliberal and postfeminist times. Subjectivity, 25(1), $432-445$.

Gill, R., \& Scharff, C. (2013). Introduction. In R. Gill \& C. Scharff (Eds.), New femininities: Postfeminism, neoliberalism and subjectivity

(pp. 1-17): Springer.

Gurley-Calvez, T., Harper, K., \& Biehl, A. (2009). Self-Employed Women and Time Use Report number SBAHQ-07-M-0409. Washington D.C.: SBA Office of Advocacy.

Gutting G \& Fraser N (2015) A feminism where 'lean in' means leaning on others. The New York Times, 15 October. Available at: http://nyti.ms/1VTH4CB (accessed Jan 25, 2018).

Harvey, D. (2005). A brief history of neoliberalism. Oxford: Oxford University Press. 
Hedlund, G. (2011). Partnerskap och genus i den regionala röran. In E. Blomberg, G. Hedlund, \& M. Wottle (Eds.), Kvinnors företagande - mål eller medel? Stockholm: SNS

Henry, C., Orser, B., Coleman, S., \& Foss, L. (2017). Women’s entrepreneurship policy: a 13 nation cross-country comparison. International Journal of Gender and Entrepreneurship(just-accepted), 00-00.

Jennings, J. E., \& Brush, C. G. (2013). Research on women entrepreneurs: challenges to (and from) the broader entrepreneurship literature? The Academy of Management Annals, 7(1), 663-715.

Jones, C., \& Spicer, A. (2005). The sublime object of entrepreneurship. Organization, 12(2), 223-246.

Kingfisher, C. (Ed.) (2013). Western welfare in decline: Globalization and women's poverty: University of Pennsylvania Press.

Klyver, K., Nielsen, S. L., \& Evald, M. R. (2013). Women's self-employment: An act of institutional (dis)integration? A multilevel, cross-country study. Journal of Business Venturing, 28(4), 474-488.

Larner, W. (2000). Neo-liberalism, policy, ideology, governmentality. Studies in political economy, 63(1), 5-25.

Lemke, T. (2001). The birth of bio-politics: Michel Foucault's lecture at the Collège de France on neo-liberal governmentality. Economy and society, 30(2), 190-207.

Lewis, P. (2014). Postfeminism, femininities and organization studies: Exploring a new agenda. Organization Studies, 35(12), 1845-1866.

Lewis, P., Benschop, Y., \& Simpson, R. (2017). Postfeminism, Gender and Organization. Gender, Work \& Organization, 24(3), 213-225.

Lewis, P., \& Simpson, R. (2016). Hakim revisited: preference, choice and the postfeminist gender regime. Gender, Work \& Organization.

Link, A. N., \& Strong, D. R. (2016). Gender and entrepreneurship: An annotated bibliography. Foundations and Trends ${ }^{\circledR}$ in Entrepreneurship, 12(4-5), 287-441.

Lombardo, E., Meier, P., \& Verloo, M. (2009). The discursive politics of gender equality: Stretching, bending and policy-making. London: Routledge.

McRobbie, A. (2004). Post-feminism and popular culture. Feminist media studies, 4(3), 255264.

McRobbie, A. (2009). The aftermath of feminism: Gender, culture and social change. London: Sage.

McRobbie, A. (2011). Beyond post-feminism. Public Policy Research(18), 179-184.

Neergaard, H., \& Thrane, C. (2011). The Nordic Welfare Model: barrier or facilitator of women's entrepreneurship in Denmark? International Journal of Gender and Entrepreneurship, 3(2), 88-104.

Nilsson, M. (2008). Rethinking redistribution. New Proposals: Journal of Marxism and Interdisciplinary Inquiry, 2(1), 31-44.

Nilsson, P. (1997). Business counselling services directed towards female entrepreneurs some legitimacy dilemmas. Entrepreneurship and Regional Development, 9(3), 239258.

Nilsson, P. (2010). Constructing p(e)ace-makers for women's enterprise. In F. Bill, B. Bjerke, \& A. W. Johansson (Eds.), (De)Mobilizing the entrepreneurship discourse (pp. 1536). Cheltenham: Edward Elgar.

Nutek. (2007). Utfall och styrning av statliga insatser för kapitalförsörjning ur ett könsperspektiv [Outcome and governance of state support for capital provision from a gender perspective] (R 2007:34). Retrieved from Stockholm: 
OECD. (2014). Enhancing Women's Economic Empowerment through Entrepreneurship and Business Leadership in OECD Countries.

Oksala, J. (2013). Feminism and neoliberal governmentality. Foucault Studies(16), 32-53.

Outshoorn, J., \& Kantola, J. (2007). Changing state feminism: Springer.

Perren, L., \& Dannreuther, C. (2013). Political signification of the entrepreneur: Temporal analysis of constructs, agency and reification. International Small Business Journal, 31(6), 603-628.

Pettersson, K. (2012). Support for women’s entrepreneurship - A Nordic spectrum. International Journal of Gender and Entrepreneurship, 4(1), 4-19.

Pettersson, K., Ahl, H., Berglund, K., \& Tillmar, M. (2017). In the name of women? Feminist readings of policies for women's entrepreneurship in Scandinavia. Scandinavian Journal of Management, 33(1), 50-63.

Pomerantz, S., Raby, R., \& Stefanik, A. (2013). Girls run the world? Caught between sexism and postfeminism in school. Gender \& Society, 27(2), 185-207.

Proposition. (1993/94:140). Bygder och regioner i utveckling. In. Stockholm: Riksdagstryck.

Proposition. (2001/02:4). En politik för tillväxt och livskraft i hela landet [A policy for growth and vitality in the whole country]. Stockholm.

Proposition. (2006/07:94). Skattelättnader för hushållstjänster, m.m. Stockholm:

Finansdepartementet Retrieved from http://www.regeringen.se/rattsdokument/proposition/2007/04/prop.-20060794/.

Rose, N. (1993). Government, authority and expertise in advanced liberalism. Economy and society, 22(3), 283-299.

Rönnblom, M. (2009). Bending towards growth: discursive constructions of gender equality in an era of governance and neoliberalism. In E. Lombardo, P. Meier, \& M. Verloo (Eds.), The discursive politics of gender equality: stretching, bending and policymaking (pp. 105-120). London: Routledge.

Sainsbury, D. (Ed.) (1999). Gender and welfare state regimes. Oxford: Oxford University Press.

SCB. (2017). Färre kvinnor än män driver företag. Retrieved from https://www.scb.se/sv_/Hitta-statistik/Artiklar/Farre-kvinnor-an-man-driver-foretag/

Scharff, C. (2016). The psychic life of neoliberalism: Mapping the contours of entrepreneurial subjectivity. Theory, Culture \& Society, 33(6), 107-122.

Skalli, L. H. (2011). Constructing Arab female leadership lessons from the Moroccan media. Gender \& Society, 25(4), 473-495.

Sköld, B. (2015). Vad hände? Kvinnors företagande och de strukturella villkoren - en studie i spåren av den offentliga sektorns omvandling. Linköping: Linköping University.

Sköld, B., \& Tillmar, M. (2015). Resilient gender order in entrepreneurship: the case of Swedish welfare industries. International Journal of Gender and Entrepreneurship, 7(1), 2-26.

Sköld, L., \& Heggeman, H. (2012). RUT vanligast efter 85. Retrieved from http://www.scb.se/sv_/Hitta-statistik/Artiklar/RUT-vanligast-efter-85/

Stacey, J. (1990). Sexism by a subtler name? Poststructural conditions and postfeminist consciousness in Silicon Valley. In K. V. Hansen \& I. J. Philipson (Eds.), A socialist feminist reader. Philadelphia: Temple University Press.

Statistics Sweden. (2016). Women and men in Sweden. Facts and figures 2016. Retrieved from Örebro:

Sullivan, K. R., \& Delaney, H. (2017). A femininity that 'giveth and taketh away': The prosperity gospel and postfeminism in the neoliberal economy. Human Relations, 70(7), 836-859. 
Sundin, E., \& Tillmar, M. (2010). The masculinization of the elderly care sector: local-level studies of public sector outsourcing. International Journal of Gender and Entrepreneurship, 2(1), 49-67.

Swanson, J. (2005). Recognition and redistribution: Rethinking culture and the economic. Theory, Culture \& Society, 22(4), 87-118.

Tasker, Y., \& Negra, D. (2007). Introduction: Feminist politica and postfeminist culture. In Y. Tasker \& D. Negra (Eds.), Interrogating postfeminism (pp. 1-26). Durham and London: Duke University Press.

Thörnquist, A. (2014). Mångfaldens retorik och arbetets praktik: Konkurrensutsättning och jämställdhet i hemtjänsten. In P. de Los Reyes (Ed.), Inte bara jämställdhet. Intersektionella perspektiv på hinder och möjligheter i arbetslivet.SOU 214:34 (pp. 115-144). Stockholm: Delegationen för jämställdhet i arbetslivet.

Tonoyan, V., Budig, M. J., \& Strohmeyer, R. (2010). Exploring the heterogeneity of women's entrepreneurship: the impact of family structure and family policies in Europe and the US. In C. Brush, A. de Bruin, E. Gatewood, \& C. Henry (Eds.), Women entrepreneurs and the global environment for growth (pp. 137-159). Cheltenham: Edward Elgar.

Winther Jørgensen, M., \& Phillips, L. (2002). Discourse analysis as theory and method. London: Sage.

Wolf, A. (2013). The XX Factor: How the Rise of Working Women Has Created a Far Less Equal World. New York: Crown.

Wottle, M., \& Blomberg, E. (2011). Feminism och jämställdhet i en nyliberal kontext 19902010 [Feminism and gender equality in a neo-liberal context 1990-2010]. [Feminism and gender equality in a neo-liberal context 1990-2010]. Tidskrift för genusvetenskap, 2011(2-3), 97-115.

Åberg, R. (2013). Tjugohundratalets arbetsmarknad-fortsatt uppkvalificering eller jobbpolarisering? Ekonomisk debatt(2), 6-15. 